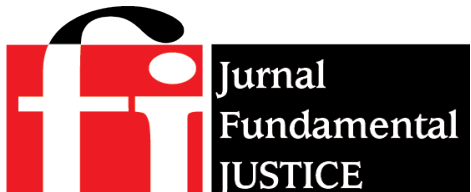

VOLUME | 1 | Nomor 1|April 2020 | ISSN : 2721-7671

| https://journal.universitasbumigora.ac.id/index.php/fundamental/navigationMenu/view/Beranda

| Prodi S1 Hukum Universitas Bumigora : DOI: https://dai.arg/I0.308/2/fundamental.vlil

\section{Pendelegasian Peraturan Dari Undang-Undang Kepada Peraturan Menteri Secara Langsung Dalam Kerangka Sistem Presidensial}

\author{
Afdalis \\ Konsultan Hukum Pada Kantor Hukum Warens \& Parners
}

Email: afdalis.lawyer@gmail.com atau afdalis@warenslaw.com

This research departs from the problem of the practice of delegating direct regulations from the law to ministerial regulations directly which has the potential to contradict the spirit of the presidential system adopted in Indonesia and the spirit of article 5 paragraph (2) of the 1945 Constitution of the Republic of Indonesia. with the aim of knowing the establishment of laws in presidential systems in Indonesia, and the practice of delegating regulations from the law to ministerial regulations directly in presidential systems in Indonesia, as well as regulatory delegators from good laws in the future. In this study, the methodology implemented was normative research. Research results show that First, the establishment of laws in Indonesian presidential systems has its own specificity. This can be seen by the establishment of a large number of laws and regulations that the President has in the Indonesian constitution. Second, direct delegation of the law to ministerial regulations is still practiced in practice, in the period 2015 to 2017 there are 16 laws that provide direct delegation to Ministerial Regulations. Direct delegation of the law to ministerial regulations philosophically seems to deny the presidential system in Indonesia. Historically, the practice of delegating regulations from the law to ministerial regulations was directly understood as part of the imperfect process of practical transformation of the parliamentary system after the Government Declaration of November 14, 1945 to the present.

\section{Key Words : Delegation of Regulations, Ministerial Regulation, Presidential System.}

Penelitian ini berangkat dari permasalahan adanya praktik pendelegasian peraturan langsung dari undang-undang kepada peraturan menteri secara langsung yang berpotensi bertentangan dengan semangat sistem presidensial yang dianut di Indonesia dan semangat pasal 5 ayat (2) UUDRI Tahun 1945. Tujuannya untuk mengetahui pembentukan undang-undang dalam sistem presidensial di Indonesia dan praktik pendelegasi peraturan dari undangundang kepada peraturan menteri secara langsung dalam sistem presidensial di Indonesia, serta pendelegasi peraturan dari undang-undang yang dimasa yang akan datang. Adapun metodologi yang digunakan adalah penelitian normatif. Hasil Penelitian menunjukkan bahwa pembentukan undang-undang dalam sistem presidensial Indonesia mempunyai ke khasan tersendiri. . Pendelegasian secara langsung dari undang-undang kepada peraturan menteri dalam praktiknya masih sering dilakukan, dalam kurun waktu 2015 sampai dengan 2017

\section{Kata kunci : Pendelegasian Wewenang, Peraturan Menteri, Sistem Presidensiil}

\section{PENDAHULUAN}

Pendelegasian pembentukan peraturan dari undang-undang kepada peraturan menteri secara langsung seharusnya dapat dihindari. Hal ini disebabkan, pendelegasian peraturan dari undangundang kepada peraturan menteri secara langsung berpotensi bertentangan dengan sistem 
presidensial yang dianut di Indonesia ${ }^{[1]}$ dan semangat pasal 5 ayat (2) Undang-Undang Dasar Negara Republik Indonesia Tahun 1945 (UUD NRI Tahun 1945) yang mengatur bahwa "Presiden menetapkan peraturan pemerintah untuk menjalankan undang-undang sebagaimana mestinya". ${ }^{[2]}$

Pembentukan hukum, dalam arti pembentukan undang-undang secara sempit dan peraturan perundang-undangan secara luas, merupakan aktivitas penting dalam negara hukum. ${ }^{[3]}$ Peraturan perundang-undangan menjadi dasar legalitas bagi seluruh elemen negara, khususnya bagi penyelenggara negara, dalam menyelenggarakan dan mengelola negara. ${ }^{[4]}$ Peraturan perundangundangan merupakan batas bertindak kekuasaan negara. ${ }^{[5]}$

Dengan urgensi yang dimilikinya, pembentukan peraturan perundang-undangan haruslah menjunjung tinggi kecermatan dalam pembentukannya, agar dapat tertib dan mudah dilaksanakan. Namun, fakta menunjukan, berdasarkan penelitian Fitriani Ahlan Sjarif, dengan meneliti bentukbentuk pembentukan peraturan delegasi dari undang-undang pada kurun waktu 1992-2012 menemukan adanya ketidakcermatan dalam pembentukan peraturan perundang-undagan khusunya pembentukan peraturan delegasi. Berdasarkan penelitian Fitriani Ahlan Sjarif terdapat enam kelompok peraturan yang diperintahkan dibentuk dari undang-undang, yakni: ${ }^{[6]}$ Peraturan Pemerintah, Peraturan Presiden, Peraturan Menteri, Peraturan Daerah, Peraturan Lembaga Negara dan Peraturan Iain-lain. Dimana dari keenam kelompok peraturan tersebut, peraturan pemerintah masih menjadi primadona, dengan presentase 39\% mendapatkan perintah delegasi. Peraturan Presiden sebanyak 5\%, Peraturan Menteri sebanyak 20\%, Peraturan Daerah 8\%, Peraturan Lembaga Negara 3\% dan Peraturan lainnya 25\%. Hal yang menarik dari penelitian Fitriani Ahlan Sjarif di atas, bahwa dari kurun waktu tersebut, Peraturan Menteri juga mendapatkan delegasi yang cukup siknifikan yakni sebanyak 20\%. Pendelegasian itu, langsung diperintahkan dari undang-undang kepada peraturan menteri.

Pola pendelegasian dari undang-undang kepada peraturan menteri secara langsung seperti di atas, dalam praktiknya masih terus berlangsung. Hal itu dapat dilihat dengan masih terdapatnya peraturan menteri yang mendapat delegasi langsung dari undang-undang. Beberapa contoh peraturan menteri yang mendapat delegasi langsung dari undang-undang diantarannya:

pertama, Peraturan Menteri Hukum dan Hak Asasi Manusia Republik Indonesia Nomor M.01HL.03.01 Tahun 2006 tentang Tata Cara Pendaftaran Untuk Memperoleh Kewarganegaraan Republik Indonesia Berdasarkan Pasal 41 dan Memperoleh Kembali Kewarganegaraan Republik Indonesia Berdasarkan Pasal 42 Undang- Undang Nomor 12 Tahun 2006 tentang Kewarganegaraan

\footnotetext{
1 Penegasan Indonesia sebagai negara dengan sistem presidensial dapat dilihat dengan ditegaskannya Presiden sebagai kepala negara sekaligus kepala pemerintahan. Pasal 4 ayat (1) UUD NRI Tahun 1945 mengatur "Presiden Republik Indonesia memegang kekuasaan pemerintahan menurut Undang-Undang Dasar”. Indonesia, Undang-Undang Dasar Negara Republik Indonesia Tahun 1945 Pasca Amandemen selama empat kali.

2 Indonesia, Undang-Undang Dasar Negara Republik Indonesia Tahun 1945 Pasca Amandemen selama empat kali. Ps. 5

3 Bagir Manan berpendapat bahwa penghargaan yang tinggi terhadap peraturan perundang-undangan menjadi salah satu ciri khas yang dianut oleh sistem hukum kontinental. Sistem hukum kontinental mengutamakan hukum tertulis, berupa peraturan perudang-undangan yang merupakan produk legislasi sebagai sendi utama sistem hukumnya. Karena itu, negaranegara yang berada dalam sistem hukum kontinental, selalu berusaha menyusun hukum-hukumnya dalam bentuk tertulis. Lihat Bagir Manan, Dasar-Dasar Perundang-Undangan di Indonesia, Cet. 1, (Jakarta: Ind-Hill-Co, 1992), hlm. 6

${ }_{4}$ Pataniari Siahaan, Politik Hukum Pembentukan Undang-Undang Pasca Amandemen Undang-Undang Dasar 1945, Cet. 1, (Jakarta: Penerbit Konpress, 2012), hlm. XIII

5 Sudargo Gautama menguraikan, salah satu corak negara hukum adalah adanya pembatasan kekuasaan negara terhadap perseorangan. Negara tidak maha kuasa. Negara tidak dapat bertindak sewenang-wenang. Tindakan negara terhadap warganya dibatasi oleh hukum. Oleh karena itu, Peraturan perundang-undangan merupakan batas bertindak kekuasaan negara. Sudargo Gautama, Pengertian tentang Negara Hukum, cet.2, (Bandung: Penerbit Alumni, 1973), hlm. 8-9

6 Fitriani Ahlan Sjarif, "Pembentukan Peraturan Delegasi Dari Undang-Undang Pada Kurun Waktu 1999-2012", (Disertasi Doktor Universitas Indonesia, Jakarta, 2015), hlm. 245
} 
Republik Indonesia. ${ }^{[7]}$ Peraturan Menteri Hukum dan HAM ini, dibentuk berdasarkan delegasi langsung dari Undang-Undang Nomor 12 Tahun 2006 tentang Kewarganegaraan Republik Indonesia dan untuk melaksanakan ketentuan Pasal 43 Undang-Undang Nomor 12 Tahun 2006 tentang Kewarganegaraan Republik Indonesia. Kedua, Peraturan Menteri Perdagangan Republik Indonesia Nomor 06/MDAG/ PER/2/2017 tentang Badan Penyelesaian Sengketa Konsumen. ${ }^{\left[{ }^{8]}\right.}$ Dalam konsideransnya, Peraturan Menteri Perdagangan ini mendapatkan delegasi berdasarkan ketentuan Pasal 49 ayat (1) Undang-UndangNomor 8 Tahun 1999 tentang Perlindungan Konsumen. Ketiga, Peraturan Menteri Kesehatan Republik Indonesia Nomor 28 Tahun 2017 tentang Izin dan Penyelenggaraan Praktik Bidan. ${ }^{[9]}$ Peraturan Menteri Kesehatan ini adalah sebagai peraturan pelaksana yang disusun berdasarkan Pasal 23 ayat (5) Undang-Undang Nomor 36 Tahun 2009 tentang Kesehatan.

Adanya pola pembentukan peraturan menteri yang mendapat delegasi secara langsung dari Undang-Undang sebagaimana di atas, menurut penulis, merupakan paradoks, apabila dikaitkan dengan sistem pemerintahan presidensial di Indonesia. Sebab, dalam sistem presidensial Indonesia, Presiden merupakan pemegang kekuasaan tertinggi dalam melaksanakan pemerintahan. Yang tentu saja berbeda dengan sistem parlementer, yang pemegang kekuasaan pemerintahan adalah Menteri (dhi. Perdana Menteri) yang memiliki hubungan secara langsung dengan koalisi di parlemen, sedangkan Presiden hanya berfungsi sebagai "simbol" dengan status kepala negara. ${ }^{[10]}$

Dalam sistem presidensial di Indonesia, Presiden menjadi kepala negara sekaligus kepala pemerintahan. ${ }^{[11]}$ Dalam menjalankan pemerintahannya, presiden dibantu menteri-menteri negara. Menteri-menteri negara diangkat dan diberhentikan oleh presiden dan bertanggung jawab langsung kepada Presiden. ${ }^{[12]}$

Pendelegasian peraturan secara langsung dari undang-undang ke peraturan menteri menimbulkan kesan bahwa DPR sebagai pemilik kedaulatan pembentukan undang-undang, secara langsung memerintahkan menteri yang merupakan pembantu Presiden. Padahal dalam Pasal 5 ayat (2) UUD NRI 1945 mengatur bahwa "Presiden menetapkan peraturan pemerintah untuk menjalankan undang-undang sebagaimana mestinya”. Artinya UUD NRI 1945 menegaskan bahwa sebaiknya ketika undang-undang sebagai peraturan otonom ingin melakukan pendelegasian, maka seharusnya pola yang dipilih adalah peraturan pemerintah.

Maria Farida Indrati S, turut mengakui kesalahan praktik pendelegasian dari undang-undang ke peraturan menteri secara langsung. Maria Farida menyatakan:

7 Indonesia, Menteri Hukum dan Hak Asasi Manusia, Peraturan Menteri Hukum dan Hak Asasi Manusia Republik Indonesia tentang Tata Cara Pendaftaran untuk Memperoleh Kewarganegaraan Republik Indonesia Berdasarkan Pasal 41 dan Memperoleh Kembali Kewarganegaraan Republik Indonesia Berdasarkan Pasal 42 Undang-Undang Nomor 12 Tahun 2006 tentang Kewarganegaraan Republik Indonesia, Peraturan Menteri Nomor M. 01-HL.0301 Tahun 2006.

8 Indonesia, Menteri Perdagangan, Peraturan Menteri Perdangan Republik Indonesia tentang Badan Penyelesaian Sengketa Konsumen, Peraturan Menteri Nomor 06/M-DAG/PER/2/2017

9 Indonesia, Menteri Kesehatan, Peraturan Menteri Kesehatan Republik Indonesia tentang Izin Penyelenggaraan Praktik Bidan, PMK Nomor 28 Tahun 2017

${ }^{10}$ Janedri M. Gaffar menguraikan Pembeda utama antara sistem parlementer dengan sistem presidensial adalah pemegang kekuasaan pemerintah. Dalam sistem parlementer, kekuasaan pemerintahan dipegang oleh parlemen. Perdana menteri bersama kabinet pemerintahan sesungguhnya adalah organ parlemen yang melaksanakan tugas pemerintahanan. Oleh karena itu, seorang perdana menteri dan para menteri dapat merangkap, bahkan lazimnya, adalah anggota parlemen. Dalam konstruksi demikian, wewenang pembentukan dan pembubaran pemerintahan sepenuhnya ada di tangan parlemen. Janedri M. Gaffar, Demokrasi Konstitusional: Praktik Ketatanegaraan Indonesia setelah Perubahan UUD 1945, cet. 1 (Jakarta: Konstitusi Press, 2012), hlm. 120

${ }^{11}$ Pasal 4 ayat (1) UUD NRI Tahun 1945 mengatur "Presiden Republik Indonesia memegang kekuasaan pemerintahan menurut Undang-Undang Dasar”. Indonesia, Undang-Undang Dasar Negara Republik Indonesia Tahun 1945, Psl. 5

${ }^{12}$ Indonesia, Undang-Undang Dasar Negara Republik Indonesia Tahun 1945, Ps. 17 
“....pembentukan peraturan menteri yang mendapat delegasi langsung dari undangundang merupakan kebiasaan yang dipengaruhi oleh Undang-Undang Dasar Sementara 1950 yang pada saat itu menganut sistem parlementer. Saat ini, pelimpahan kewenangan (delegasi) yang diberikan langsung dari Undang-undang adalah hal yang tidak tepat. Karena pasal 5 ayat (2) UUD 1945 telah dengan tegas menyatakan bahwa Presiden membentuk Peraturan Pemerintah untuk menjalankan undang-undang sebagaimana mestinya". ${ }^{[13]}$

Berdasarkan konstruksi ini, maka setiap undang-undang yang memerlukan suatu peraturan pelaksanaan seharusnya dilaksanakan lebih lanjut dengan peraturan pemerintah. Sebagai peraturan yang telah digariskan dalam UUD NRI Tahun 1945. Dalam konteks pembentukan undang-undang dimasa yang akan datang, pemberian delegasi dari undang-undang kepada peraturan menteri secara langsung sebaiknya harus dihindari untuk menjaga tertib pembentukan peraturan perundangundangan.

Sistem pemerintahan terdiri dari dua kata, yaitu sistem dan pemerintahan. Masing-masing kata tersebut, mempunyai pengertian, yang apabila digabungkan, kedua kata tersebut menjadi suatu pengertian yang berkaitan dengan sistem ketatanegaraan. ${ }^{[14]}$ Dilihat dari segi etimologi, kata sistem merupakan terjemahan dari kata system (bahasa inggris) yang berarti susunan, tatanan, jaringan, atau cara. Sedangkan pemerintahan berasal dari kata pemerintah, dan pemerintah berasal dari kata perintah. ${ }^{[15]}$ Dalam Kamus Besar Bahasa Indonesia, kata perintah, Pemerintah dan pemerintahan diartikan: ${ }^{[16]}$

a. Perintah adalah perkataan yang bermakna menyuruh melakukan sesuatu.

b. Pemerintah adalah kekuasaan yang memerintah suatu wilayah, daerah, atau negara.

c. Pemerintahan adalah perbuatan memerintah yang dilakukan oleh badan-badan legislatif, eksekutif, dan yudikatif di suatu begara dalam rangka mencapai tujuan penyelenggaraan negara.

Terdapat banyak pendapat ahli yang telah memberikan batasan terkait pengertian sistem pemerintahan. batasan tersebut diantaranya disampaikan oleh Bintang R. Saragih, Jimly Asshiddiqie, Jenedri M. Gaffar, Hanta Yuda, dan Mahmud MD. Berdasarkan pendapat beberapa ahli ini, terlihat bahwa sistem pemerintahan merupaka hubungan dan tata kerja antara lembagalembaga negara. Lembaga negara yang dimaksud adalah lembaga eksekutif dan lembaga legislatif. Dimana pola hubungan ini menghasilkan bentuk sistem pemerintahan.

Berkaitan dengan model atau bentuk-bentuk sistem pemerintahan, terdapat banyak pembagian model sistem pemerintahan. Jimly Asshidiqqie, membagi model sistem pemerintahan menjadi tiga kategori, yaitu, sistem pemerintahan presidesial (presidential system), sistem pemerintahan parlementer (parliamentary system), dan sistem semi presidensial atau sistem campuran (mixed system atau hybrid system). ${ }^{[17]}$ Pembagian yang hampir sama juga disampaikan oleh mahfud MD, yang membagi tiga model sistem pemerintahan negara yaitu presidensial, parlementer dan referendum. ${ }^{[18]}$ Uraian yang hampir samajuga di uraiakan oleh Arend Lijphart sebagaimana dikutip oleh Fitra Arsil ${ }^{[19]}$

${ }^{13}$ Maria Farida Indrawati S, Ilmu Perundang-Undangan: Jenis, Fungsi dan Materi Muatan, (Yogyakarta: Penerbit Kanisius, 2007), hlm . 227-228

${ }^{14}$ Dasril Radjab, Hukum Tata Negara Indonesia, Cet. 2, (Jakarta: PT RINEKA CIPTA, 2005), hlm. 64

${ }^{15}$ Inue Kencana Syafie, Sistem Pemerintahan Indonesia, (Yogyakarta: Rineka Cipta, 2011), hlm. 38

${ }_{16}$ KBBI Daring, Definisi Kata Perintah, Pemerintah dan Pemerintahan, https://kbbi.kemdikbud.go.id/, diakses 28 Juli 2018.

17 Jimly Asshiddiqie, Pengantar Hukum Tata Negara Jilid II, Cet. 1, (Jakarta: KonPress, 2006), hlm. 59

${ }^{18}$ Moh. Mahfud MD, Demokrasi dan Konstitusi di Indonesia: Studi tentang Interaksi Politik dan Kehidupan Ketatanegaraan, (Jakarta: Rineka Cipta, 2000), hlm. 74

${ }^{19}$ Arend Lijphart, Patterns of Democracy: Government Forms and Performance in Thirty-Six Countries, (New Heaven: Yale 
Berdasarkan beberapa pembagian ahli di atas, terlihat bahwa secara umum, sistem pemerintahan yang dikenal di dunia secara garis besar dibedakan kedalam 3 (tiga) bentuk, yaitu, sistem pemerintahan Presidensial, sistem pemerintahan parlementer dan Sistem Pemerintahan Semi Presidensial (campuran).

Dalam Pembentukan Peraturan Perundang-Undangan kepustakaan hukum ditemukan berbagai istilah yang erat kaitannya dengan pembentukan peraturan perundang undangan. Istilah-istilah tersebut antara lain: pembuatan peraturan perudang-undangan, penyusunan peraturan perundangundangan, perancagan peraturan perundang-undangan, dan pembentukan peraturan perundangundangan. Namun, pengunaan berbagai istilah-istilah tersebut sebenarnya dimaksudkan untuk menunjukkan pada kegiatan lembaga negara atau pemerintahan yang berdasarkan kewenangannya membuat suatu jenis peraturan perundang-undangan.[21]

Mengacu kepada istilah baku yang digunakan di dalam UU No. 12 Tahun 2011, istilah yang dipilih adalah pembentukan peraturan perundang-undangan. ${ }^{[22]}$ Pembentukan peraturan perundangundangan dapat diartikan sebagai fungsi pembentukan hukum oleh pejabat atau badan/lembaga negara atau pemerintahan diluar putusan pengadilan, berdasarkan kewenangannya (otoritasnnya) membuat suatu peraturan perundang-undangan. Pengertian membentuk peraturan perundangundangan ini mencakup kegiatan yang dimulai dari perencanaan, persiapan, teknik penyusunan, perumusan, pembahasan, pengesahan, pengundangan dan penyebarluasan. ${ }^{[23]}$

Landasan hukum pembentukan peraturan perundang-undangan di Indonesia, dapat dilihat dalam UU No. 12 Tahun 2011 dan UU Nomor 17 Tahun 2014 tentang Majelis Permusyawaratan rakyat, Dewan Perwakilan Rakyat, Dewan Perwakilan Daerah, dan Dewan Perwakilan Rakyat Daerah (UU MD3) ${ }^{[24]}$ serta peraturan turunan lainnya.

Bentuk penelitian dalam rangka penyusunan makalah ini adalah penelitian yuridis normatif, yaitu dalam melakukan pembahasan terhadap permasalahan yang ada dalam penulisan ini dikaitkan dengan ketentuan hukum yang berlaku dan konsep-konsep hukum yang berkaitan

Universuty Press, 1999), hlm. 116-121, dikutip dalam Fitra Arsil, "Koalisi partai Politik di Indonesia: Kajian Terhadap Pengaturan dan Praktik Terkait Koalisi Partai Politik di Indonesia Periode 1945-1959 dan 1998-2014". Disertasi, (Jakarta, Program Pacasarjana UI, 2015), hlm. 34 juga dapat di baca dalam Fitra Arsil, Teori Sistem Pemerintahan:Pergeseran Konsep dan Saling Kontribusi Antar Sistem Pemerintahan di Berbagai Negara, cet. 1, (Depok: Rajawali Press, 2017), hlm. 14

${ }^{20}$ Jose Antonio Cheibub, Presidentialism, Parliamentiarism, and Demokracy,(New York: Cambridge University Press, 2007),hlm. 33-44 dikutip dalam Fitra Arsil, "Koalisi partai Politik di Indonesia: Kajian Terhadap Pengaturan dan Praktik Terkait Koalisi Partai Politik di Indonesia Periode 1945-1959 dan 1998-2014". Disertasi, (Jakarta, Program Pacasarjana UI, 2015), hlm. 35 juga dibaca dalam Fitra Arsil, Teori Sistem Pemerintahan:Pergeseran Konsep dan Saling Kontribusi Antar Sistem Pemerintahan di Berbagai Negara, cet. 1, (Depok: Rajawali Press, 2017), hlm. 15

${ }^{21}$ King Faisal Sulaiman, Teori Peraturan Perundang-Undagan dan Aspek Pengujiannya, Cet. 1 (Yogyakarta: Thafa Media, 2017), hal. 4

${ }^{22}$ Istilah pembentukan peraturan perundang-undangan juga banyak dipilih oleh ahli karena berbagai alasan, diantarannya: pertama, dalam hukum positif, istilah yang digunakan adalah pembentukan peraturan perundang-undagan, sebagaimana judul UU Nomor 12 Tahun 2011. Kedua, konsep pembetukan peraturan perundang-undangan secara teoritikal merupakan bagian dari konsep pembentukan hukum. Ketiga, pembentukan peraturan perundang-undangan mengandung makna tidak sekedar menggambarkan kegiatan lembaga atau badan pembentuk peraturan perundang-undangan, tetapi juga mengandung makna fungsi pembentukan hukum yang dilakukan oleh badan atau lembaga negara/pemerintahan. Widodo Ekatjahjana, Pembentukan Peraturan Perundang-Undangan: Dasar-Dasar dan Teknik Penyusunannya, Cet. 1 (Bandung: PT Citra Aditya Bakti), hal. 1 bandingkan dengan King Faisal Sulaiman, Teori Peraturan Perundang-Undagan dan Aspek Pengujiannya, Cet. 1 (Yogyakarta: Thafa Media, 2017), hal. 4

${ }^{23}$ Widodo Ekatjahjana, Pembentukan Peraturan Perundang-Undangan: Dasar-Dasar dan Teknik Penyusunannya, Cet. 1 (Bandung: PT Citra Aditya Bakti), hal. 2

${ }^{24}$ Indonesia, Undang-Undang tentang tentang Majelis Permusyawaratan rakyat, Dewan Perwakilan Rakyat, Dewan Perwakilan Daerah, dan Dewan Perwakilan Rakyat Daerah, UU Nomor 17 Tahun 2014, LN Tahun 2014 Nomor 182 TLN Nomor 5568 
dengan permasalahan. Bentuk penelitian ini dipilih karena sesuai dengan tujuan penelitian yakni untuk mengetahui pendelegasian peraturan dari undang-undang kepada peraturan menteri dalam kerangka sistem presidensial. Penelitian ini mengunakan tiga pendekatan yakni: ${ }^{[25]}$ Pertama, Pendekatan perundang-undangan (statute approach). Kedua, Pendekatan konseptual (conseptual approach). Ketiga, Pendekatan sejarah (historical approach). Dan Keempat, Pendekatan perbandingan (comparative approach).

\section{PEMBAHASAN}

\section{A. Pengaruh Sistem Presidensial dalam Pembentukan Undang-Undang}

Salah satu karakteristik dasar sistem presidensial adalah adanya pemisahan kekuasaan secara tegas antara cabang eksekutif dan cabang kekuasaan legislatif. ${ }^{[26]}$ Dengan adanya pemisahan kekuasaaan ini, maka konsekuensi yang timbul adalah kedua kekuasaan akan fokus pada kewenagan masing-masing. Meskipun dalam beberapa aspek dapat saja keduanya saling mengawasi dalam kerangka check and balances ${ }^{[27]}$.

Pemisahan yang tegas antara cabang kekuasaan eksekutif dan legislatif dalam sistem presidensial, turut membawa pengaruh pada pola pembentukan undang-undang atau fungsi legislasi. Dalam hal ini, fungsi legislasi yang di praktikkan pada negara-negara dengan sistem presidensial, memiliki corak yang berbeda dengan negara-negara dengan sistem parlementer. Saldi Isra, menguraikan perbedaan corak pembentukan peraturan perudang-undangan antara sistem presidensial dan parlemeter dengan menyatakan bahwa:

“....fungsi legislasi dalam sistem parlementer berbeda dengan fungsi legislasi dalam sistem presidensial. Fungsi legislasi dalam sistem parlementer ditandai dengan adanya ketergantungan eksekutif yang tinggi terhadap dukungan parlemen dan tidak adanya pemisahan yang tegas antara cabang eksekutif dan cagang legisatif. ${ }^{[28]}$ Sedangkan dalam sistem presidensial ditandai dengan adanya pemisahan yang tegas antara cabang kekuasaan eksekutif dan cabang kekuasaan legislatif. ${ }^{[29]}$

Dengan demikian, pilihan sistem pemerintahan suatu negara akan membawa pengaruh pada mekanisme pembentukan undang-undangnya.

${ }^{25}$ Johnny Ibrahim menguraikan, dalam penelitian normatif, dapat digunakan beberapa pendekatan, yaitu: pendekatan perundang-undangan (statute approach), pendekatan sejarah (historical approach), pendekatan konseptual (conseptual approach) dan pendekatan perbandingan (comparative approach). Lihat Johnny Ibrahim, Teori dan Metodologi Penelitian Hukum Normatif (Edisi Revisi),(Malang: Bayumedia Publishing, 2007), hlm. 300

${ }^{26}$ Karakter lainya dapat dilihat lebih lengkap dalam uraian bab dua tesis ini, tepatnya pada point tinjaun umum sistem pemerintahan. Berdasarkan pendapat beberapa ahli, penulis melihat bahwa karakteristik mendasar sistem presidensial diantaranya, (1) Adanya pemisahan kekuasaan antara kekuasaan legislatif dan kekuasaan eksekutif, (2) Presiden mempunyai fungsi ganda, yakni sebagai kepala negara sekaligus kepala pemerintahan; (3) Adanya kedudukan setara antara legislatif dan eksekutif, sehingga presiden tidak dapat membubarkan parlemen. (4) Presiden maupun dewan perwakilan rakyat sama-sama dipilih oleh rakyat sebagai pemilik sah kedaulatan. (5) Adanya pembatasan masa jabatan presiden, (6) Presiden tidak bertanggung jawab kepada parlemen, melainkan bertanggung jawab langsung ke rakyat. Lihat kembali halaman 42-43.

${ }^{27}$ Dalam uraian teori pemisahan kekuasaan, Istilah checks and balances sendiri dapat dimaknai sebagai "arrangement of governmental power where by powers of one governmental branch check or balance those of other brances". Atau dengan kata lain, checks and balances merupakan sebuah prinsip dimana antar cabang kekuasaan saling mengawasi dan menyeimbangkan. Munir Fuady, memberikan pengertian checks merupakan suatu pengontrolan atau pengawasan dari cabang kekuasaan yang satu dengan cabang kekuasaan yang lain agar tidak ada yang berbuat sewenang-wenang yang menyebabkan salah satu cabang kekuasaan mendominasi. Sedangkan balances adalah penyeimbangan agar salah satu dari cabang kekuasaan tidak ada yang lebih kuat dari cabang kekuasaan yang lain sehingga terhindar dari otoritarianisme/tirani. Lihat ulang urain dalam bab pendahuluan tesis ini, hlm. 16

${ }^{28}$ Saldi Isra, Pergeseran Fungsi Legislasi: Menguatnya Model Legislasi Parlementer dalam Sistem Presidensial Indonesia, cet. 2 (Jakarta: RajaGrafindo Persada, 2013), hlm. 79

${ }^{29} \mathrm{Ibid}, \mathrm{hlm} .82$ 
Paul Christoper Manuel dan Anne M. Camissa, melihat karakter mendasar dari sistem presidensial dalam pembentukan undang-undnag adalah separation of legislative (congressional) dan executive (presidensial power). Dengan pemisahan itu, dalam sistem presidensial, badan legislatif menentukan agendanya sendiri, membahas dan menyetujui rancangan undang-undang pun sendiri pula. Biasanya, lembaga legislatif mengusulkan dan memformulasikan dan dapat bekerja sama dengan eksekutif dalam merumuskan legislasi, terutama pada saat partai politik yang sama berkuasa di kedua cabang pemerintahan ini." ${ }^{[30]}$

Saldi isra dengan mengutip pendapat beberapa ahli menguraikan karakter umum fungsi legislasi dalam sistem presidensial adalah sebagai berikut:

1. The legislature tends to have broad powers to amend any legislations. Lack of resources, and other factors may act to blunt this power.

2. The potential for legislative assertiveness is greater in presidential systems, but the actual realization (and staffing up for assertiveness) depends on the presence of other conditions.

3. Legislatures in presidential system are more likely to have specialized and permanent standing committees and subcommittees with a number of professional staff to help draft, review and amend legislation.

4. Via the committee system, the legislature has extensive power to call expert witnesses, members of cabinet, presidential advisors, etc, for public or private hearings before legislature.

5. The presidensial can veto legislation, which can only be overridden by a $2 / 3$ vote in the legislature. ${ }^{[31]}$

Dari hal tersebut di atas, terlihat bahwa karakter umum pembentukan peraturan perundang undangan dalam sistem presidensial, terdapatnya kekuasaan besar yang dimiliki oleh legislatif. Meskipun dalam praktik kekuasaan tersebut mungkin saja berkurang karena banyak factor. Factor tersebut antara lain, keterbatasan sumber daya manusia, besarnya kekuatan pendukung partai politik presiden dilembaga legislatif, dan sistem kepartaian dominan fungsi legislasi berada di tangan lembaga legislatif. Oleh karena itu, Presiden diberikan hak untuk menolak (berupa hak veto) rancangan undang-undang yang sudah disetujui legislatif. Meskipun, hak veto tersebut masih dapat dibatalkan lembaga legislatif dengan komposisi suara tertentu.

\section{B. Undang-Undang Pada Kurun Waktu 2015 yang Memberikan Delegasi Langsung ke Peraturan Menteri.}

Tahun 2015 merupakan tahun awal pelaksanaan tugas anggota Dewan Perwakilan Rakyat Republik Indonesia (DPR RI) hasil pemilu umum tahun 2014. Pada tahun 2015 pembentuk undangundang menetapkan 14 (empat belas) undang-undang. ${ }^{[32]}$ Materi undang-undang yang ditetapkan tahun 2015 lebih banyak berkisar pada undang-undang pengesahan perjanjian internasional yakni sebanyak lima undang undang, penetapan peraturan pemerintah penganti undang-undang sebanyak tiga undang-undang, perubahan undang-undang lama sebanyak tiga undang-undang, satu pencabutan undang-undang, dan penetapan anggaran pendapatan dan belanja negara serta pertangung jawaban anggaran pendapatan dan belanja negara tahun sebelumnya.

Dari 14 Undang-Undang yang berhasil di sahkan tahun 2015, terdapat dua undang-undang yang

30 Ibid

31 Ibid, hlm. 82-83

32 Jaringan Dokumentasi Informasi Hukum Nasional Badan Pembinaan Hukum Nasional, "Undang-Undang Yang disahkan Tahun 2015”, http://jdihn.bphn.go.id/perperaturan/164?tahun=2015, diakses tanggal 1 September 2018. Diakses tanggal 10 September 2018. 
memberikan delegasi langsung kepada peraturan menteri, satu undang-undang yang memberikan delegasi keperaturan pemerintah, dan yang sisahnya tidak memberikan perintah delegasi. Kedua undang-undang tersebut yakni undang-undang nomor 8 tahun 2015 tentang Perubahan Atas Undang-Undang Nomor 1 Tahun 2015 tentang Penetapan Peraturan Pemerintah Pengganti Undang-Undang Nomor 1 Tahun 2014 tentang Pemilihan Gubernur, Bupati, dan Walikota Menjadi Undang-Undang ${ }^{[33]}$ dan Undang-Undang Nomor 14 tahun 2015 tentang Anggaran Pendapatan dan Belanja Negara Tahun Anggaran 2016 ${ }^{[34]}$.

\section{Undang-Undang Pada Kurun Waktu 2016 yang Memberikan Delegasi Langsung ke Peraturan Menteri.}

Pada tahun 2016 pembentuk undang-undang menetapkan 20 (dua puluh) undangundang. ${ }^{[35]}$ Materi undang-undang tersebut diantaranya adalah beberapa pengesahan perjanjian internasional, penetapan peraturan pemerintah penganti undang-undang, pertanggung jawaban atas pelaksanaananggaran pendapatan dan belanja negara tahun 2016, beberapa Perubahan undang undang, dan undang-undang yang memuat materi baru yang dianggap menjadi kebutuhan masyarakat. Pada tahun 2016, terdapat delapan undang-undang yang memberikan delegasi langsung kepada peraturan menteri. Undang-undang tersebut antara lain:

1. Undang-Undang Nomor 7 Tahun 2016 tentang Perlindungan dan Pemberdayaan Nelayan Pembudi Daya Ikan dan Petambak Garam. Perintah pendelegasian itu dapat dilihat dalam Pasal 35 dan 72 ayat (3).

2. Undang-Undang Nomor 8 Tahun 2016 tentang Penyandang Disabilitas. Perintah pendelegasian itu dapat dilihat dalam Pasal 121 ayat (3).

3. Undang-Undang Nomor 10 Tahun 2016 tentang Perubahan Kedua Atas Undang-undang Nomor 1 Tahun 2015 tentang Penetapan Peraturan Pemerintah Pengganti Undangundang Nomor 1 Tahun 2014 Tentang Pemilihan Gubernur Bupati dan Walikota Menjadi Undang-undang. Perintah pendelegasian itu dapat dilihat dalam Pasal 166 ayat (3).

4. Undang-Undang Nomor 11 Tahun 2016 tentang Pengampunan Pajak. Perintah Pendelegasian itu dapat dilihat Pasal 24.

5. Undang-Undang Nomor 12 Tahun 2016 tentang Perubahan Atas Undang-Undang Nomor 14 Tahun 2015 Tentang Anggaran Pendapatan dan Belanja Negara Tahun 2016. Perintah pendelegasian itu dapat dilihat dalam Pasal 12 ayat (4B).

6. Undang-Undang Nomor 13 Tahun 2016 tentang Paten. Perintah pendelegasian itu dapat dilhat dalam pasal 18, Pasal 29, Pasal 32, Pasal 33 ayat (3), Pasal 42, Pasal 53 ayat (6), Pasal 56, Pasal 66, Pasal 73, Pasal 80, Pasal 88, Pasal 107.

7. Undang-Undang Nomor 18 Tahun 2016 tentang Anggaran Pendapatan dan Belanja Negara Tahun Anggaran 2017. Dimana perintah pendelegasian itu dapat dilihat dalam Pasal 15 ayat (4), Pasal 17, Pasal 23 ayat (4), Pasal 24 ayat (3), Pasal 25 ayat (3), Pasal 26 ayat (4), Pasal 29 ayat (3), Pasal 32 ayat (6), Pasal 33 ayat (5), dll.

8. Undang-Undang Nomor 20 Tahun 2016 tentang Merek dan Indikasi Geografis. Perintah

${ }^{33}$ Indonesia, Undang-Undang tentang Perubahan Atas Undang-Undang Nomor 1 Tahun 2015 tentang Penetapan Peraturan Pemerintah Penganti Undang-Undang Nomor 1 Tahun 2014 tentang Pemilihan Gubernur, Bupati, dan Wakilota Menjadi UndangUndang, UU Nomor 8 tahun 2015, LN Tahun 2015 No. 57, TLN No. 5678

${ }^{34}$ Indonesia, Undang-Undang tentang Anggaran Pendapatan dan Belanja Negara Tahun Anggaran 2016, UU Nomor 14 Tahun 2015, LN Tahun 2015 No. 278, TLN No. 5767

35 Jaringan Dokumentasi Informasi Hukum Nasional Badan Pembinaan Hukum Nasional, "Undang-Undang Yang disahkan Tahun 2016”, http://jdihn.bphn.go.id/perperaturan/164?tahun=2016, diakses tanggal 18 September 2018 
pendelegasian itu dapat dilihat dalam Pasal 6 ayat (3), Pasal 8, Pasal 21 ayat (4), 23 ayat (8), Pasal 27 ayat (3), Pasal 39 ayat (3), Pasal 40 ayat (4), Pasal 41 ayat (9), Pasal 45 dll.

\section{Undang-Undang dalam Kurun Waktu 2017 yang Memberikan Delegasi Langsung ke Peraturan Menteri.}

Pada tahun 2017 pembentuk undang-undang menetapkan 18 (delapan belas) UndangUndang. ${ }^{[36]}$ Materi Undang-Undang tersebut diantara adalah beberapa pengesahan perjanjian internasional, pertanggung jawaban atas pelaksanaananggaran pendapatan dan belanja negara tahun 2016, beberapa perubahan undang undang, dan penetapan anggaran pendapatan dan belanja negara tahun anggaran 2018, penetapan peraturan pemerintah penganti undang-undang. Undang-Undang tersebut diantaranya:

1. Undang-Undang Nomor 2 Tahun 2016 tentang Jasa Konstruksi. Perintah pendelegasian itu dapat dilihat pada Pasal 20 ayat (4), Pasal 30 ayat (7), Pasal 31 ayat (5), Pasal 35, Pasal 37 ayat (4), Pasal 64, Pasal 66 ayat (2), Pasal 68 ayat (4), Pasal 69 ayat (7), Pasal 71 ayat (6), Pasal 72 ayat (4), Pasal 74 ayat (7), Pasal 83 ayat (6).

2. Undang-Undang Nomor 3 Tahun 2017 tentang Sistem Perbukuan. Perintah pendelegasian itu dapat dilihat pada Pasal 63 ayat (4), Pasal 65 ayat (4), Pasal 65 ayat (5).

3. Undang-Undnag Nomor 5 Tahun 2017 tentang Pemajuan Kebudayaan. Perintah pendelegasian itu dapat dilihat pada Pasal 37 ayat (4), Pasal 38 ayat (4).

4. Undang-Undang Nomor 6 Tahun 2017 tentang Arsitek. Perintah pendelegasian dapat dilihat pada Pasal 5 ayat (4), Pasal 19 ayat (4).

5. Undang-Undang Nomor 8 Tahun 2017 tentang Perubahan Atas Undang-Undang Nomor 18 Tahun 2016 tentang Anggaran Pendapatan dan Belanja Negara Tahun Anggaran 2017. Perintah pendelegasian itu dapat dilihat pada Pasal 11 ayat (12B), Pasal 12 ayat (6C), Pasal 13ayat (12B).

6. Undang-Undang Nomor 18 Tahun 2017 tentang Pelindungan Pekerja Migran Indonesia. Perintah pendelegasian itu dapat dilihat pada Pasal 29 ayat (5), Pasal 32 ayat (4), Pasal 37 ayat (2), Pasal 51 ayat (3), Pasal 55 ayat (3), Pasal 57 ayat (5), Pasal 60, Pasal 61 ayat (3), Pasal 74 ayat (2).

\section{E. Aspek Filosofis Pendelegasian Peraturan dari undang-undang secara langsung kepada Peraturan menteri dalam Kerangka Sistem Pemerintahan Presidensial.}

Terjadi perubahan kekuasaan pembentukan undang-undang dari eksekutif ke legislatif dalam hal ini DPR. Jika sebelum perubahan UUD NRI tahun 1945 kekuasan pembentukan undangundang berada ditangan presiden sebagaimana ditegaskan dalam pasal Pasal 4 ayat (1) UUD NRI Tahun 1945 bahwa "Presiden Republik Indonesia memegang kekuasaan pemerintahan menurut UndangUndang Dasar", setelah amandemen selama empat kali, kekuasaan itu bergeser ke tangan DPR sebagaimana tegaskan dalam pasal 20 ayat (1) UUD NRI Tahun 1945 bahwa "Dewan Perwakilan Rakyat memegang kekuasaan membentuk undang-undang". ${ }^{[3]}$

Dengan konstruksi demikian, menurut penulis kekuasaan pembentukan undang-undang saat ini berada ditangan DPR. ${ }^{[38]}$ Dengan asumsi demikian, maka ketika undang-undang yang

36 Jaringan Dokumentasi Informasi Hukum Nasional Badan Pembinaan Hukum Nasional, "Undang-Undang Yang disahkan Tahun 2017”, http://jdihn.bphn.go.id/perperaturan/164?tahun=2017, diakses tanggal 20 September 2018

${ }_{37}$ Uraian mengenai pergeseran kekuasaan pembentukan peraturan perundang-undangan ini telah dibahas dalam pembahasan bab dua

${ }^{38}$ Walaupun beberapa ahli berbendapat bahwa pergeseran ini hanya pergeseran secara tekstual. Misalnya, menurut saldi $r 37$
+57. 
merupakan produk dari lembaga legislatif mendelegasikan secara langsung pelaksanaan teknis undang-undang tersebut kepada Peraturan Menteri. Maka secara tidak langsung membuat kesan bahwa Menteri diperintahkan langsung oleh DPR, dengan menegasikan Presiden sebagai pemilik kekuasaan tertinggi dalam pemerintahan. ${ }^{[39]}$

Pendelegisian secara langsung langsung dari undang-undang kepada peraturan menteri menurut penulis, menegasikan kekuasaan Presiden sebagai pemilik kekuasaan pemerintahan. dimana menteri dalam pelaksanaan pemerintahan berkedudukan sebagai pembantu Presiden, yang bertanggung jawab kepada Presiden. Pendelegasian secara langsung ini menimbulkan kesan, bahwa menteri mendapatkan perintah dari DPR yang merupakan ciri pelaksaan kekuasaan pada negara dengan sistem parlementer.

Dalam sistem parlementer menempatkan kekuasaan eksekutif sebagai bagian dari lembaga legislatif. Hal tersebut menurut Robert I. Maddex sebagaimana dikutip oleh Saldi Isra membawa konsekuensi bahwa antar cabang kekuasaan eksekutif dan legislatif harus bekerja sama. ${ }^{[40]}$ Proses yang demikian merupakan konsekuensi logis dari pola koalisi partai politik yang menjadi mayoritas di parlemen. Adanya kekuatan politik mayoritas di parlemen tersebut membuat urusan-urusan pemerintah yang terkait dengan parlemen termasuk fungsi legislasi menjadi lebih mudah dilaksanakan. Lebih lanjut, Saldi Isra mengutip Michael L. Mezey yang menyatakan bahwa "legislator dalam sistem pemerintahan parlementer membentuk sekaligus merupakan pendukung pemerintah." ${ }^{[41]}$

Berdasarkan uraian tersebut, maka Pendelegisian secara langsung langsung dari undangundang kepada peraturan menteri terkesan menegasikan sistem pemerintahan presidensial di Indonesia, di mana Presiden merupakan pemilik kekuasaan pemerintahan.

\section{F. Aspek Historis Pendelegasian Peraturan dari undang-undang secara langsung kepada Peraturan menteri dalam Kerangka Sistem Pemerintahan Presidensial.}

Pembentukan Peraturan Menteri secara historis dapat dilihat pertama kali pada UndangUndang Nomor 1 Tahun 1950. Dalam Pasal 1 UU tersebut, disebutkan bahwa jenis-jenis peraturan Pemerintah Pusat ialah:

1. Undang-Undang dan Peraturan Pemerintah Pengganti Undang-Undang (PERPU);

2. Peraturan Pemerintah;

Isra, "Pendapat-Pendapat yang mengatakan bahwa perubahan Pasal 5 ayat (1) dan Pasal 20 ayat (1) UUD 1945 menyebabkan terjadinya pergeseran fungsi legislasi atau kekuasaan pembentukan undang-undang dari presiden kepada DPR hanya dapat dibenarkan dari perubahan bunyi teks yang terdapat dalam kedua pasal hasil perubahan UUD 1945 tersebut. Namun, jika diletakkan dalam pengertian legislation is an aggregate, not a simple production, tidak tepat mengatakan bahwa kekuasaan membentuk undang-undang sepenuhnya berada di tangan DPR, atau Presiden bukan lagi pemegang kekuasaan pembentukan undang-undang. Dengan adanya rumusan Pasal 5 ayat (1) UUD 1945 yang menyatakan bahwa presiden berhak mengajukan rancangan undangundang kepada DPR, presiden tetap menjadi bagian dari proses legislasi. Lihat Saldi Isra, Pergeseran Fungsi Legislasi..., hlm. 323.

Tetapi, menurut penulis perubahan tekstual itu membawa pengaruh besar. Penulis mendasarkan argumentasi pada pendapat Jimly Asshiddiqie bahwa UUD NRI Tahun 1945 telah menggariskan bahwa kedaulatan berada ditangan rakyat. Dengan demikian, pada prinsipnya kewenangan legislasi juga berada ditangan rakyat. Rakyat direpresentasikan oleh parlemen yaitu Dewan Perwakilan Rakyat. Konsekuensi logis dari hal ini, maka Dewan Perwakilan Rakyatlah yang memiliki kekuasaan murni pembentukan undang-undang. Lihat Jimly Asshiddiqqie, Perihal Undang-Undang, (Jakarta: Konstitusi Press, 2006), hlm. 215

39 Pasal 4 ayat (1) UUD 1945 yang menyatakan bahwa Presiden Republik Indonesia memegang kekuasaan pemerintahan menurut Undang-Undang Dasar.

${ }^{40}$ Saldi Isra, Pergeseran Fungsi Legislasi....., hlm. 81.

${ }^{41}$ Ibid 
Hamid Attamimi dalam disertasinya menyoroti ketiadaan Peraturan Presiden dan justru Peraturan oleh Menteri yang dimunculkan. ${ }^{[42]}$ Menurut Hamid Attamimi, hal tersebut terjadi karena sejak 14 November 1945 sistem pemerintahan Indonesia bergeser dari yang semula adalah sistem presidensial ke parlementer. ${ }^{[43]}$ Dalam sistem parlementer, Presiden berada pada kedudukan yang tidak dapat diganggu-gugat, sedangkan tanggung jawab tentang pemerintahan berada di tangan menteri, maka dari itu pada masa itu hampir tidak ada peraturan yang dibuat oleh Presiden. ${ }^{[4]}$

Pada periode tahun 1949-1950, Negara Indonesia berbentuk Republik Indonesia Serikat dengan sistem pemerintahan parlementer berdasarkan Konstitusi RIS tahun 1949. Konstitusi RIS 1949 meneguhkan praktik sistem parlementer (sistem tanggung jawab menteri) seperti yang termaktub dalam Maklumat Pemerintah Nomor 14 November 1945. Menurut Saldi Isra, karakter sistem pemerintahan parlementer dalam konstitusi RIS, yaitu: ${ }^{[45]}$

1. Pemisahan antara kepala negara dengan kepala pemerintahan. Kepala negara dilakukan oleh Presiden sedangkan kepala pemerintahan dipegang oleh Perdana Menteri.

2. Sebagai kepala negara, kekuasaan Presiden tidak dapat diganggu-gugat;

3. Menteri-menteri bertanggung jawab baik sendiri-sendiri maupun secara bersama-sama. Artinya jika kebijakan menteri atau menteri-menteri tidak diterima DPR maka menteri atau kabinet harus mengundurkan diri.

4. Lembaga legislatif merupakan badan perwakilan dengan sistem dua kamar (bicameral system) sehingga fungsi legislasi dilakukan secara bersama-sama antara pemerintah dan DPR serta Senat.

Maria Farida, melihat praktik pendelegasian dari undang-undang ke peraturan menteri secara langsung merupakan praktik tidak sempurna perubahan dari sistem parlemter ke sistem presidensial. Maria Farida menyatakan:

"pembentukan peraturan menteri yang mendapat delegasi langsung dari undangundang merupakan kebiasaan yang dipengaruhi oleh Undang-Undang Dasar Sementara 1950 yang pada saat itu menganut sistem parlementer. ${ }^{[46]}$

Berdasarkan hal tersebut maka dapat dipahami bahwa secara historis, praktik pendelegasian peraturan dari undang-undang kepada peraturan menteri secara langsung merupakan transformasi praktikal yang tidak sempurna dari sistem parlementer pasca Maklumat Pemerintah 14 November 1945.

\section{G. Aspek Yuridis-Formal Pendelegasian Peraturan dari undang-undang secara langsung kepada Peraturan menteri dalam Kerangka Sistem Pemerintahan Presidensial.}

42 A. Hamid S. Attamimi, "Peranan Keputusan Presiden Republik Indonesia dalam Penyelenggaraan Pemerintahan Negara: Suatu Studi Analisis Mengenai Keputusan Presiden Yang Berfungsi Pengaturan dalam Kurun Waktu Pelita I - Pelita IV”. Disertasi (Jakarta: Fakultas Pascasarjana Universitas Indonesia, 1990), hlm. 230

43 Perubahan sistem pemerintahan terjadi pasca dikeluarkannya Maklumat Pemerintah pada tanggal 14 November 1945. Dalam maklumat tersebut, prinsip pertanggungjawaban menteri-menteri dengan resmi diakui. Menteri menteri menjadi anggota dari kabinet yang dipimpin oleh seorang Perdana Menteri dan tidak lagi bertanggungjawab kepada Presiden. Oleh karena itu pusat kekuasaan eksekutif telah bergeser dari Presiden kepada Perdana Menteri. Lihat Ismail Suny, Pergeseran Kekuasaan Eksekutif, (Jakarta: Aksara Baru, cet-6, 1986), hlm. 31

${ }^{44}$ Ibid

${ }^{45}$ Saldi Isra, Pergeseran Fungsi Legislasi...., hlm. 115.

${ }^{46}$ Maria Farida Indrawati S, Ilmu Perundang-Undangan: Jenis, Fungsi dan Materi Muatan, (Yogyakarta: Penerbit Kanisius, 2007), hlm . 227-228 
Secara Yuridis formal, sebagaimana di jelaskan dalam pembahasan sebelumnya bahwa pendelegasan peraturan dari undang-undang kepada peraturan menteri secara langsung tidak menyalahi ketentuan di dalam Undang-Undang. Pasal 7 UU Nomor 12 Tahun 2011 menguraikan mengenai tata urutan (hierarki) peraturan perundang-undangan di Indonesia yaitu:

1. Undang-Undang Dasar Negara Republik Indonesia Tahun 1945;

2. Ketetapan Majelis Permusyawaratan Rakyat;

3. Undang-Undang/Peraturan Pemerintah Pengganti Undang-Undang;

4. Peraturan Pemerintah;

5. Peraturan Presiden;

6. Peraturan Daerah Provinsi; dan

7. Peraturan Daerah Kabupaten/Kota.

Yang kemudian Pasal 8 ayat (1) UU Nomor 12 Tahun 2011, mengatur:

“Jenis Peraturan Perundang-undangan selain sebagaimana dimaksud dalam Pasal 7 ayat (1) mencakup peraturan yang ditetapkan oleh Majelis Permusyawaratan Rakyat, Dewan Perwakilan Rakyat, Dewan Perwakilan Daerah, Mahkamah Agung, Mahkamah Konstitusi, Badan Pemeriksa Keuangan, Komisi Yudisial, Bank Indonesia, Menteri, badan, lembaga, atau komisi yang setingkat yang dibentuk dengan Undang-Undang atau Pemerintah atas perintah Undang-Undang, Dewan Perwakilan Rakyat Daerah Provinsi, Gubernur, Dewan Perwakilan Rakyat Daerah Kabupaten/Kota, Bupati/Walikota, Kepala Desaatauyangsetingkat." $[47]$

Lebih lanjut dalam Pasal 8 ayat (2) UU Nomor 12 Tahun 2011 menyatakan bahwa Peraturan Perundang-undangan sebagaimana dimaksud pada ayat (1) diakui keberadaannya dan mempunyai kekuatan hukum mengikat sepanjang diperintahkan oleh Peraturan Perundang-undangan yang lebih tinggi atau dibentuk berdasarkan kewenangan. ${ }^{[48]}$

Berdasarkan konsruksi ini maka Peraturan Menteri merupakan peraturan yang sah diakui sebagai bagian peraturan perundang-undangan asalkan terlebih dahulu mendapatkan perintah delegasi. Yang kemudian dalam lampiran 2 Undang-Undang Nomor 12 Tahun 2011 tentang Pembentukan Peraturan Perundang-undangan, memberikan kemungkinan adanya pendelegasian kewenangan mengatur dari undang-undang kepada menteri, pemimpin lembaga pemerintah nonkementerian, atau pejabat yang setingkat dengan menteri. Pendelegasian kewenangan ini kemudian dipersyaratkan dengan hanya membatasi untuk peraturan yang bersifat teknis administratif. ${ }^{[49]}$

\section{H. Usulan Pembentukan Peraturan Delegasi di Masa Yang Akan Datang}

Berdasarkan permasalahan dan kekurangan yang terjadi terkait pendelegasian secara langsung dari Undang-Undang kepada Peraturan Menteri dalam kerangka Sistem Presidensial sebagaimana analisis penulis pada sub-bab sebelumnya, dengan demikian dalam penelitian ini, penulis memberikan beberapa usulan yang dapat dilakukan dalam rangka menjamin pelaksanaan pendelegasian secara langsung dari Undang-Undang kepada Peraturan Menteri dapat di hindari sehingga sesuai dengan semangat sistem presidensial dan amanat Pasal 5 ayat (2) Undang-Undang Dasar Negara Republik Indonesia Tahun 1945. Adapun usulan tersebut diantarannya: Pertama, mendorong perubahan Undang-Undang Nomor 12 Tahun 2011. Kedua, perlunya penegasan bahwa

${ }^{47}$ Indonesia, Undang-Undang tentang Pembentukan Peraturan Perundang-Undangan, UU 12 Tahun 2011, LN Tahun 2011 Nomor 82, TLN Nomor 5234, psl. 8

${ }^{48}$ Ibid

${ }^{49}$ Point 211, Lampiran II Undang-Undang Nomor 12 Tahun 2011 tentang Pembentukan Peraturan Perundang-Undangan. 
hanya peraturan pemeritah dalam hal ini peraturan pemeritah dan peraturan presiden yang dapat dijadikan penerima delegasi dari undang-undang. Ketiga, perlunya pemahaman para pihak yang berkepentingan dalam pembentukan peraturan perundang-undangan.

\section{KESIMPULAN}

1. Berdasarkan konstitusi Repubik Indonesia, dalam hal ini Undang-Undang Dasar Negara Republik Indonesia Tahun 1945. Pembentukan undang-undang dalam sistem presidensial Indonesia mempunyai ke khasan tersendiri. Hal itu dapat dilihat dengan adanya kekuasaan pembentukan peraturan perundang-undangan yang besar yang dimiliki Presiden, Presiden dengan persetujuan bersama Dewan Perwakilan Rakyat membentuk Undang-Undang, dan Presiden memiliki kewenangan membuat peraturan pemerintah sebagai pelaksana undang-undang.

2. Pendelegasian secara langsung dari undang-undang kepada peraturan menteri dalam praktiknya masih sering dilakukan, dalam kurun waktu 2015 sampai dengan 2017 terdapat 52 undangundang yang disahkan, dari 52 undang-undang tersebut, terdapat 16 undang-undang yang memberikan delegasi langsung kepada Peraturan Menteri. Pendelegasian secara langsung dari undang-undang kepada peraturan menteri secara filosifis terkesan mengingkari sistem presidensial di Indonesia yang menempatkan Presiden sebagai Kepala Negara sekaligus kepala Pemerintahan dan Menteri Negara berkedudukan sebagai pembantu Presiden yang bertanggung jawab kepada Presiden. Secara historis, praktik pendelegasian peraturan dari undang-undang kepada peraturan menteri secara langsung dipahami sebagai bagian dari proses transformasi praktikal yang tidak sempurna dari sistem parlementer pasca Maklumat Pemerintah 14 November 1945 hingga saat ini. Sedangkan secara yuridis formal, Undang-Undang Dasar Negara Republik Indonesia Tahun 1945 baik sebelum dan sesudah amandemen empat kali menegaskan Pendelegasian dari undang-undang sebaiknya dibuat dengan Peraturan Pemerintah, dan Undang-Undang Nomor 12 Tahun 2011 dalam Lampiran II Peraturannya, memberikan peluang dimungkinkannya pendelegasian secara langsung dari Undang-Undang kepada Peraturan Menteri.

3. Pendelegasian dari undang-undang dimasa yang akan datang, sebaiknya hanya didelegasikan kepada peraturan pemerintah. Dalam hal ini peraturan pemerintah dan peraturan presiden. Hal ini dapat diwujudkan dengan merevisi Undang-Undang Nomor 12 Tahun 2011 tentang Pembentukan Peraturan Perundang-Undangan sebagai pedoman pembentukan peraturan perundang-undangan dan memberikan pemahaman kepada para pihak terkait dalam pembentukan peraturan perundang-undangan.

Adapun saran dalam penyusunan undang-undang, lembaga legislasi (baik Pemerintah maupun DPR) hendaknya tidak hanya fokus pada aspek formal pembentukan peraturan perundangundangan saja, tetapi juga berpegang pada aspek filosofis di dalam konstitusi, agar praktikpraktik pendelegasian dari undang-undang kepada peraturan menteri secara langsung dapat dihindari. Serta Lembaga legislasi (baik Pemerintah maupun DPR) hendaknya menyesuaikan penyusunan perundang-undangan dengan semangat sistem pemerintahan presidensial, dimana Presiden adalah sebagai pemegang kekuasaan menjalankan pemerintahan yang sekaligus lembaga yang menjalankan undang-undang yang dibuat oleh legislator. Dengan begitu, setiap peraturan pelaksana dari undang-undang hendaknya dilaksanakan secara hierarkis melalui Peraturan Pemerintah maupun Peraturan Presiden terlebih dahulu. Agar revisi terhadap Undang-Undang Nomor 12 Tahun 2011 tentang Pembentukan Peraturan Perundang-Undangan, segera dilakukan dan dalam subtansi pengaturannya dimasukkan penegasan bahwa hanya Peraturan Pemeritah

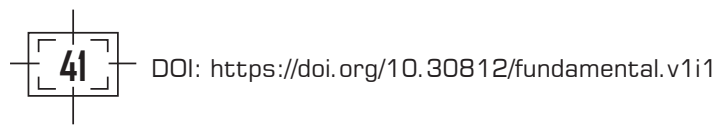


Afdalis $\mid$ Pendelegasian Peraturan Dari Undang-Undang Kepada Peraturan Menteri Secara Langsung.

(Peraturan Pemeritah dan Peraturan Presiden) yang dapat menjadi delegasi dari undang-undang.

\section{DAFTAR REFERENSI}

\section{A. Buku}

Abdoellah, Priyamanto. Revitalisasi Kewenangan PTUN Gagasan Perluasan Kompetensi Peradilan Tata Usaha Negara. Cet. 1. Yogyakarta: Cahaya Atma Pustaka. 2016.

Asshiddiqie, Jimly. Perihal Undang-undang. Cet. 1. (Jakarta: Konstitusi Press. 2006.

Perkembangan dan Konsolidasi Lembaga Negara Pasca Reformasi. Cet.2. Jakarta: Konstitusi Press. 2006.

. Pengantar Hukum Tata Negara. Cet. 2. Jakarta: Rajawali Press. 2010.

Ekatjahjana, Widodo. Pembentukan Peraturan Perundang-Undangan. Cet.1. Bandung: Penerbit PT Citra Aditya Bakti. 2008.

Gaffar, Janedri M. Demokrasi Konstitusional: Praktik Ketatanegaraan Indonesia setelah Perubahan UUD 1945. Cet. 1. Jakarta: Konstitusi Press. 2012.

Gautama, Sudargo. Pengertian tentang Negara Hukum. Cet.2. Bandung: Penerbit Alumni. 1973.

Ibrahim, Johnny. Teori dan Metodologi Penelitian Hukum Normatif. Edisi Revisi. Malang: Bayumedia Publishing. 2007.

Indrati S, Maria Farida. Ilmu Perundang-Undangan Dasar dan Pembentukannya.Yogyakarta: Kanisius. 1998.

Ilmu Perundang-Undangan: Jenis, Fungsi dan Materi Muatan. Yogyakarta: Penerbit Kanisius. 2007.

. Ilmu Perundang-Undangan: Proses dan Teknik Pembentukannya. Yogyakarta: PT Kanisius, 2007.

Manan, Bagir. Dasar-Dasar Perundang-Undangan di Indonesia. Cet. 1. Jakarta: Ind-Hill-Co, 1992.

MD, Moh. Mahfud. Demokrasi dan Konstitusi di Indonesia: Studi tentang Interaksi Politik dan Kehidupan Ketatanegaraan. Jakarta: Rineka Cipta. 2000.

Radjab, Dasril. Hukum Tata Negara Indonesia. Cet. 2. Jakarta: PT RINEKA CIPTA, 2005.

Siahaan, Pataniari. Politik Hukum Pembentukan Undang-Undang Pasca Amandemen Undang-Undang Dasar 1945. Cet. 1. Jakarta: Penerbit Konpress. 2012.

Sulaiman, King Faisal. Teori Peraturan Perundang-Undagan dan Aspek Pengujiannya. Cet. 1. Yogyakarta: Thafa Media. 2017.

Syafie, Inue Kencana. Sistem Pemerintahan Indonesia. Yogyakarta: Rineka Cipta. 2011.

\section{B. Peraturan Perundang-Undangan}

Indonesia, Undang-Undang Dasar Negara Republik Indonesia Tahun 1945.

Indonesia. Undang-Undang tentang Pembentukan Peraturan Peraturan Perundang-Undangan. UU No. 10 Tahun 2004. LN Tahun 2004 No. 53. TLN No. 4389.

Indonesia. Menteri Hukum dan Hak Asasi Manusia. Peraturan Menteri Hukum dan Hak Asasi Manusia RepublikIndonesiatentang Tata Cara PendaftaranuntukMemperoleh Kewarganegaraan Republik Indonesia Berdasarkan Pasal 41 dan Memperoleh Kembali Kewarganegaraan Republik Indonesia Berdasarkan Pasal 42 Undang- Undang Nomor 12 Tahun 2006 tentang Kewarganegaraan Republik Indonesia. Peraturan Menteri Nomor M. 01-HL.0301 Tahun 2006.

Indonesia. Menteri Perdagangan. Peraturan Menteri Perdangan Republik Indonesia tentang Badan Penyelesaian Sengketa Konsume., Peraturan Menteri Perdagangan Nomor 06/M-DAG/ 
Indonesia. Menteri Kesehatan. Peraturan Menteri Kesehatan Republik Indonesia tentang Izin Penyelenggaraan Praktik Bidan. PMK Nomor 28 Tahun 2011

\section{Penelitian}

Attamimi, A. Hamid S. "Peranan Keputusan Republik Indonesia dalam Penyelenggaraan Pemerintahan Negara: Studi Analisis Mengenai Keputusan Presiden Yang Berfungsi Pengaturan Dalam Kurun Waktu Pelita 1-Pelita IV”. Disertasi Doktor Universitas Indonesia. Jakarta, 1990.

Arsil, Fitra. "Koalisi Partai Politik di Indonesia: Kajian Terhadap Pengaturan dan Praktik Terkait Koalisi Partai Politik di Indonesia Periode 1945-1959 dan 1998-2014". Disertasi Doktor Universitas Indonesia. Jakarta, 2015.

Sjarif, Fitriani Ahlan. "Pembentukan Peraturan Delegasi Dari Undang-Undang Pada Kurun Waktu 19992012”. Disertasi Doktor Universitas Indonesia. Jakarta, 2015. 
